\title{
The Threat to Indonesia From the Islamic State of Iraq and Syria (IS/ISIS): A Human Security Perspective
}

\author{
Sukawarsini Djelantik \\ Parahyangan Catholic University, Bandung, Indonesia
}

\begin{abstract}
The democratization process in the Middle East and North Africa (MENA), better known as the Arab Spring, led to increased instability in the region. The civil war in Syria coupled with the attacks by the Islamic State of Iraq and Syria (ISIS) or later known as the Islamic State (IS) has resulted in one of the largest humanitarian crises since World War II. This security threat has spread to other regions, including Southeast Asia. Indonesia, with the biggest Moslems population in Southeast Asia, has been affected most significantly in comparison to other ASEAN member countries. ISIS has acknowledged its terrorist actions which involved suicide bomb attacks, and also claimed membership all over the archipelago. The continuing violence and resulting threats or feeling of insecurity negatively affect the lives, freedom, dignity, and development of the people. Not only related to political and military, the threat also affected human security, including economic, environmental, social, and other forms of harm done by the overall livelihood and wellbeing of individuals. Other threats related to the recruitment process of new ISIS member made use of conventional and social media. This article aims to answer the question: "How has ISIS threatened human security in Indonesia?” Another question is: How has the Indonesian government reacted to securitize the above issues? It concluded that the government has not comprehensively solved the issues to reduce human security threats in Indonesia.
\end{abstract}

Keywords: cooperation, regionalism, securitization, Southeast-Asia, terrorism

\section{Background: About ISIS/IS}

The Islamic State of Iraq and Syria (ISIS) was declared on 9 April 2013 by Abu Bakar Al Baghdadi in Syria. ISIS has become one of the most important jihadist groups against the government of Syria and has established a military base in Iraq. ${ }^{1}$ By the end of July 2014, ISIS changed its name into Islamic State (IS) to widen the scope of Islamic caliphates in the world. ${ }^{2}$ Roughly $80 \%$ of Western combatants in Syria are predicted to have joined this organization. ${ }^{3}$

ISIS has turned into the most dangerous terrorist group in the world. It had successfully developed military

Sukawarsini Djelantik, Ph.D., International Relations Department, Parahyangan Catholic University, Bandung, Indonesia.

1 NU Online, http://www.nu.or.id/a.public-m,dinamic-s,detail-ids,45-id,53669-lang,id-c,internasional-t,Bagaimana+Sejarah+ Terbentuknya+ISIS+-phpx, accessed on July 28th, 2015.

2 Euronews, http://www.euronews.com/2014/06/30/isil-renames-itself-islamic-state-and-declares-caliphate-in-captured-territory/, accessed on August 19th, 2015.

3 The Washington Freebeacon, http://freebeacon.com/national-security/new-al-qaeda-group-produces-recruitment-material-for-americans-westerners/, accessed on August 19th, 2015. 
forces, and took control of Raqqa in 2013 and Mosul in Syria in 2014. The group has been infamous for its terrorist actions, atrocities, and various violations of human rights, especially those against its ideology. ISIS violence has been demonstrated in its various forms of social media propaganda. In Indonesia, ISIS has claimed responsibility to several terrorism activities, such as the 2016 Jakarta bomb attack, in addition to several bomb attacks targeted all over the country from Sabang in Northern Sumatra, to Merauke in Papua. ISIS declared responsibility after its troops (or the Khalifah) conducted the action.

The emergence of ISIS has led to insecurity and instability in the Middle East, and has spread to other regions. The continuing instability in Iraq and Syria had led one of the largest humanitarian crises since World War II. During ISIS controls the region, the escalated military approaches have inflamed the violence, with the consequence of increasing the number of victims among civilians. The insecurity has affected the lives, freedom, and dignity of the Syrian, who fled mostly to European countries. To establish the new utopian state of ISIS which fully implemented Islamic Law, several forms of propaganda have been applied to attract people from all over the globe. In Southeast Asia, ISIS members predominantly originated from Indonesia, Malaysia, and the Southern Philippines. Indonesia with its majority population of Moslems is the biggest supplier of people to the ISIS region. They believe that to fight on the side of ISIS as Jundallah or soldiers of God, they conduct Jihad, fighting for the glory of Islam.

With the recent development in 2016, and the loss that ISIS suffered after several air strikes by the USA led coalition, ISIS fighters asked to continue their struggle elsewhere, avoiding ISIS-controlled regions. In Indonesia, ISIS and supporters had even established a Katibah Nusantara (KN), or Daulah Islamiyah, covering Malay speaking individuals mostly from Indonesia, Malaysia, Singapore, and the Southern Philippines. The $\mathrm{KN}$ initiated terrorist attacks that led to instability and insecurity in Indonesia.

For the above reasons, this paper aims to explore human security aspects of the crisis in Indonesia. It will firstly discuss the background of the emergence of ISIS in Indonesia. The human security analysis will be using the seven points of human security as introduced by the United Nations Development Program (UNDP) in 1994. Special attention will be paid to individuals and community threats, followed by a focus on political and economic aspects. Further analysis would zoom in on securitization program of the Indonesian government, and its effectiveness to reduce threats and regain security. The state of security will be achieved after the government's ability to restore peace, minimize violence, mitigating the effects and protecting the people. Further analysis will be made of the efforts of securitization actors to conduct anti-terrorism measures.

\section{Literature Review}

Several articles related to human security issues have been useful by way of reference to this paper. The first is T. S. Hataley and Kim Richard Nossal's article: “The Limits of the Human Security Agenda: The Case of Canada’s Response to the Timor Crisis”. ${ }^{4}$ The article analyzed the Canadian's government actions under the presidency of Prime Minister Chretien and Foreign Minister Lloyd Axworthy to respond to the 1999 East Timor crisis. The article argued that, to respond to the humanitarian issue, the state's political interest was more significant, while ignoring the human security aspects. The issue was approached using the freedom from fear

\footnotetext{
${ }^{4}$ Hataley, T. S., and K. R. Nossal, “The Limits of the Human Security Agenda: The Case of Canada's Response to the Timor Crisis”, The Journal of Clobal Peace and https://www.tandfonline.com/doi/full/10.1080/1478115042000176148?scroll=top\&needAccess=true, accessed on May 17th, 2018.
} 
concept to adapt to human security. The second article was written by Isaac Kfir, entitled: "Social Identity Group and Human (In)Security: The Case of Islamic State in Iraq and the Levant (ISIL)" ${ }^{5}$ It explores the continued allure of Al-Qaeda's ideology, focusing on the three key aspects of grievance, insecurity, and religion. The article further explores on how ISIS has exploited these factors to become the most dangerous branch of Al-Qaedism. Kfir argued that it is not religion that lies at Al-Qaeda's ideological base, but grievance and insecurity, with religion employed or even exploited to justify violence. The article suggested that the way to engage with ISIS is by adopting policies that undermine the reasons why people turn to the groups for security. Even though there are several other articles related to human security and terrorism, none has discussed ISIS as a specific terrorist group, its operation in Indonesia, and how the group affected insecurity. For this reason, this paper would be useful to provide a better understanding of how ISIS affected human insecurity in Indonesia.

\section{Human Security Issues}

The Human Development Report of the UNDP first introduced the human security concept in $1994{ }^{6}$ The concept proposed a more comprehensive approach to security, which did not only focus on state security. The concept of human security primarily focuses on protecting the integral worth of people against insecurity rather than protecting the state. People are placed at the center of this response and it focuses on the circumstances that threaten the well-being and survival of the people. As a result, the promotion of human security does not lead to a military response or defend, instead it promotes and develops aspects such as human rights and economic conditions. Focusing on the security of people entails that human rights be of primary concern and therefore take precedence over state sovereignty. As human security aims to promote equity, solidarity, freedom, and dignity, the people are seen as "equal actors to the state in international relations" (1994/2018). ${ }^{7}$

The human security concept is the result of globalization and our interconnected world, viewing human security as a freedom from fear and freedom from want. The concept covers security from physical threat and the integrity of human psychology. ${ }^{8}$ Another form of human security is related to freedom from want in the broadest sense, which includes the threat to socio-economic conditions. The issue of terrorism by ISIS has surely threatened all human security aspects, but this paper will only focus on economic, individual, community, and political insecurity.

\section{ISIS as Security Threat to Indonesia}

ISIS Indonesia was proclaimed by Bachrumsyah alias Abu Muhammad Al Indonesi in 2014. Most of the ISIS supporters and sympathizers are drawn from existing jihadist groups. The most prominent militant leaders are Bahrun Naim, Abu Jandal, or Chep Hernawan, the self-proclaimed “president” of “ISIS Indonesia”. Aman Abdurrahman from Jamaah Anshorut Tauhid (JAT) is the most prominent ideologist responsible for introducing ISIS in Indonesia. He is currently detained at Nusakambangan (a prison for severe punishment), in

\footnotetext{
${ }^{5}$ Isaac Kfir, “Social Identity Group and Human (In)Security: The Case of Islamic State in Iraq and the Levant (ISIL)”, Studies in Conflict and Terrorism, Vol. 38, 2015, Issue No. 4, see: https://www.tandfonline.com/doi/abs/10.1080/1057610X.2014.997510, accessed on May 17th, 2018.

6 UNDP Team, http://hdr.undp.org/sites/default/files/reports/255/hdr_1994_en_complete_nostats.pdf, “Human Development Report 1994”, Oxford University Press, 1994, accessed on May 15th, 2018.

7 Ibid.

8 Ibid.
} 
Central Java. The exact number of ISIS members remains unknown, however, according to the Indonesian intelligence unit (BIN), approximately 514 originate from all over the archipelago.

The government and other related institution are overwhelmed by the task of having to reduce the number of Indonesian ISIS combatants that departed to Syria. The national anti-terrorism agency (BNPT) has worked alongside its Foreign Terrorist Fighter (FTF) to prevent the entry of Indonesian citizen to Syria. The amount of ISIS members from Indonesia has risen three times in a few months; June 2014 (86 persons) and October 2014 (264 persons), most of them were Indonesian citizen that have lived in a neighboring country as a student or immigrant before the establishment of ISIS. Indonesia become the first IS member contributor (514 persons), followed by Malaysia (40 persons), Philippines (200 persons), and Australia (60 persons). Compared to the Mujahidin that fought in Afghanistan from 1985 to 1994, the total amount does not even reach 300 people. When they came back, they were equipped with the ability and experience in battle fields, tactics, and weaponry, beside showing deeper commitment towards the ideology, and forming a stronger international network. Although the number is small, it is sufficient to make them leaders of a small number of Indonesian extremists.

In Malaysia and Singapore, ISIS supporters could be arrested once they had left the country and were suspected to join an illegal group. The Indonesian security apparatuses, however, are not supported by a legal basis to arrest suspected members, unless supported by strong evidence. The security officer in charge should implement lawful conduct or otherwise be condemned as violating human rights. Unless ISIS members are caught while carrying guns or are planning an attack, they should be released. The dilemma between preventing a terrorist attack from the early stage of operation and providing adequate evidence has also been acknowledged by the National Intelligence Unit (BIN). In addition, most of terrorist action plans were managed through social media communication, especially the one called a Telegram as favorite application. ${ }^{9}$ During the recent May 2018 waves of terrorist attacks, the usage of telegram was replaced by game communications online. The terrorist involved used an end-to end-encryption (E2EE) games application to avoid the government's surveillance system. ${ }^{10}$ Social media are used massively to campaign jihad and to attract new members that the government considered as common enemy. Joining the group could have created solidarity among them.

\section{Individual and Societal Threat}

ISIS has conducted several terrorist attacks since its establishment in 2013. All attacks have increased insecurity and the threat of loss of life to those finding themselves in the wrong place at the wrong time. The deadliest attack after the 2002 Bali Bomb took place in May 2018 in Surabaya, the capital city of East Java. The near simultaneous bomb blasts attacking three churches killed 14 people and left many injured. Since the beginning of May 2018, at least 49 Indonesians (consisting of 12 civilians, seven police officers, and 30 terrorists) died in back-to-back attacks by ISIS supporters or government antiterrorism operations. The May 2018 waves of terrorist actions also happened in Sidoarjo, Bekasi, in Medan and in Pekanbaru in Sumatra Island.

\footnotetext{
9 British Broadcasting Communication (BBC), Kapolri: “Telegram Saluran Komunikasi Favorit Teroris”, http://www.bbc.com/indonesia/indonesia-40622484, accessed on May 31st, 2018.

10 Okezone, https://techno.okezone.com/read/2018/05/14/326/1898228/melalui-aplikasi-games-teroris-bisa-saling-berkomunikasi, accessed on May 31st, 2018.
} 
The increasing threat of ISIS to individuals is demonstrated by the use of women and children as suicide bombers. The May 2018 attacks demonstrated the ISIS shift of tactics with the participation of women and children. Beside religious minorities, law enforcement remains the target of ISIS. Previously there was an ISIS-linked jail riot at the Police Station in Depok, in South Jakarta. Most of the inmates in the section have been linked to the Islamic State, and the terrorist group's media arm claimed responsibility for the uprising. ${ }^{11}$ The attacks in May 8th, 2018 happened only two days before the beginning of the holy month of Ramadan. This month is typically a time of renewed militancy among extremists.

Individual and societal threats are also indicated by the growing number of Foreign Terrorist Fighters (FTF) returnees from the ISIS region. The family returnees have not all been living in the ISIS region. Some of them had attempted to join ISIS but were deported before crossing the border. After their arrival in Indonesia, the deportees are generally put through a rudimentary rehabilitation program, but the government lacks the capacity to monitor them after the completion of these short courses. The Indonesian government has made efforts to securitize the issue through its de-radicalization program under the anti-terrorism National Agency (BNPT). The program was not very effective, as it is conducted for only a few days. Afterwards, there was a failure in monitoring returnee activities. Several bomb attacks conducted by ISIS family deportees demonstrated the ineffectiveness of the program.

Another securitization program was conducted by the government through the establishment of an anti-terror unit under the Indonesian National Police, the Special Detachment (Densus 88). The special unit and the BNPT, have implemented a mechanism and strategy that can ensure the protection of personal security and human rights. The two units assisted in realizing human security by "shifting operations of warfare to that of law enforcement. Moreover, the units have been minimizing the amount of force used in order to protect people against casualties”. Human rights, freedoms, and dignity are secured by focusing on empowering and protecting the people who are affected by these forms of insecurity.

Even though the Densus 88 and BNPT have effectively combated terrorism, ISIS threats remain by the massive use of social media for membership recruitment. ISIS has been using these social media for propaganda by way of various platform and methods. In the era of information technology, the ability of social media management differentiates ISIS from other terrorist groups. ISIS has maintained at least 46 thousand Twitter accounts ${ }^{12}$ mostly controlled from Syria, Iraq, and Saudi Arabia.

The ability of ISIS to recruit more and more foreigners has demonstrated the effectiveness of communication through social media. The Indonesian government, through the Minister of Communications and Information Technology, had closed down several webpages of radical groups. ${ }^{13}$ The close-down was aimed at preventing the widespread phenomena of radicalism through cyberspace. Radical messages are posted online to facilitate the proliferation of deviant doctrines. An example of an ISIS communication was found after the May 2018 prison attack in Jakarta. One telegram message read: “Support in your own cities the mujahedeen

\footnotetext{
11 Kompas, https://nasional.kompas.com/read/2018/05/09/01231621/kerusuhan-di-mako-brimob-kelapa-dua-dipicu-cekcoktahanan-dengan-petugas, accessed on May 31st, 2018.

12 J. M. Berger and Jonathan Morgan, “The ISIS Twitter Census: Defining and Describing the Population of ISIS Supporters on Twitter":

http://www.brookings.edu/ /media/research/files/papers/2015/03/isis-twitter-census-berger-morgan/isis_twitter_census_berger_m organ.pdf, accessed on September 15th, 2015.

13 https://seminyaktimes.com/cyberwars-indonesian-government-threatens-closure-social-media-platforms/, accessed on May 23rd, 2018.
} 
(Islamic guerilla fighters) who caused the riot! Burn the assets of nonbelievers, idolaters, apostates, and hypocrites! Burn their malls! Destroy the economy of the nonbelievers by withdrawing your money from their banks! The momentum only comes once; don't fail to use it” (2018). ${ }^{14}$

ISIS Indonesia has used all different types of social media, such as Twitter, Facebook, and Youtube for propaganda, recruitment, and spread of ideology purposes. In this informative era, ISIS has become more and more dependent on the social media in its operation. Even though Twitter has tried to tackle ISIS's threats, propaganda, and recruitment by freezing those-particular accounts, sympathy still flows and thousands of other accounts are still active. Even though ISIS's social media accounts were being closed regularly, they keep making new accounts and maintaining their strong online presence. ${ }^{15}$ ISIS has tried to expand its reach into other alternative social media, such as Quitter, Friendica, and Diaspora. ${ }^{16}$

ISIS was declared to be an illegal organization by the Indonesian government in August 2014. Previously, ISIS propaganda had been conducted through T-shirt sales with written slogans like "Mujahidin All Across the World Unite", "Fight for Freedom to Death", and "We Support ISIS”. These online sales took place through websites owned by Indonesian online entrepreneurs. ${ }^{17}$ After the government declared ISIS to be an illegal organization, the promotion website and advertisements became unavailable to public view. All social media companies applied the same rule of banning any direct message that promotes violence and threats. ${ }^{18}$ Considering the significant role of social media, the government used the social media to monitor, analyze, and combat terrorism. ISIS has changed its strategy that is to say from violence to ideological approach to build a civilization based on Islamic Law. ISIS propaganda has successfully attracted new members to practice the best aspects of living in areas controlled by ISIS. This strategy has successfully moved people to hijrah and refers to the members as muhajir or muhjirah. ${ }^{19}$

\section{Economic Threats}

The biggest motivation to join ISIS was ideological, or a desire to live in a country which fully implements the Islamic Sharia. The second motivation is economical, related to the promise of a salary up to USD 2000/month. In addition, children and family members are promised USD 200/month plus other allowances such as education and health. The salary of soldiers is between USD 400-1,200 per month. For soldiers' wives, the allowance is USD 50/person, and USD 35 for each child. Slaves received USD 50 and their children USD 35. Parents of militants receive allowances of USD 50. However, the amount has been decreased, especially to those living in Raqqa, and in 2016 they only obtained USD 50/month. ${ }^{20}$ With the income, the members also hope to make the pilgrimage to Mecca as the fifth obligation for being Moslems. The offer is

\footnotetext{
14 Sydney Jones, 2018, “How ISIS Has Changed Terrorism in Indonesia”, see: https://www.nytimes.com/2018/05/22/opinion/isis-terrorism-indonesia-women.html, assessed on May 23rd, 2018.

ISIS $\quad$ Faces $\quad$ Resistance $\quad$ From $\quad$ Social
http://blog.adl.org/extremism/isis-faces-resistance-from-social-media-companies, accessed on August 19th, 2015.

16 Ibid.

17 Fox News, http://www.foxnews.com/tech/2014/06/23/facebook-pulls-jihadi-sites-hawking-isis-gear-after-foxnewscomquery.html, accessed on September 19th, 2015.

18 Syria World, http://www.vocativ.com/world/syria-world/isis-tries-outwit-social-networks/, accessed on September 19 th, 2015.

19 The Hijrah, is the migration or journey of the Islamic prophet Muhammad and his followers from Mecca to Medina, in the year 622. In ISIS term, the term has been used to describe a foreign fighter's journey from his/her country of origin to terrorist-held territories abroad. See: Counter Extremism, https://www.counterextremism.com/content/hijrah, accessed on May $23 r d, 2018$.

${ }^{20}$ Data of the Congressional Research Service, http://bisnis.liputan6.com/read/2416333/intip-besaran-gaji-tentara-isis, accessed on September 28th, 2016.
} 
quite attractive especially to middle-lower income groups who are unemployed, and desperate. The situation is closely related to the Indonesian economy, which has not fully recovered since the global economic crisis in 2000. Even though the period of 2010-2016 demonstrated that the Indonesian economy has seen impressive growth $^{21}$, the condition at grass-root level remains an issue. During the period of 2010-2016, the unemployment rate was high, with the number of people living below the poverty line amounting to $10.86 \%$ of the total population (equivalent to 28.01 million). ${ }^{22}$ The data further demonstrate that the poverty level is higher in rural areas in comparison to urban areas. This fact explains why the ISIS recruitment was successful and more appealing to people living in rural areas.

The success of ISIS to attract membership is supported by the fact that this is more than an ordinary terrorist group. ISIS was supported by wealth to run its organization as well as attract membership by promising economic advantages. ISIS received its wealth from the Syrian oil fields seized from the legal government. ISIS funds were obtained from the control of at least 11 oil fields in Iraq and Syria with revenue of around two million pound sterling per day. ${ }^{23}$ As ISIS controls most of Syria's oil fields and crude oil, this is the militant group's biggest single source of revenue. Since 2012, ISIS had been snatching and controlling several important facilities that formerly belonged to the Iraqi and Syrian governments. Some of the oil fields controlled by ISIS were Sasan, Ajeel, and Sadid in Iraq, as well as huge oil fields in Baiji, Fallujah, Aksas, and Tikrit. ISIS also controlled the Qayyara field near Mosul in Northern Iraq. A US-led coalition air strike on ISIS oil effectively disrupted its crude extraction. Before the coalition strikes, ISIS was estimated to earn approximately USD 1.5 million per day. Other ISIS sources of income consist of taxation, extortion, and tithe (zakat). ${ }^{24}$ ISIS also obtained wealth from looting, taking foreign national hostage, ransom demands from the families of victims and those facing death sentences. Following the decreasing economy of ISIS after the US-led coalition's air strikes, the soldiers' salary was also cut. ${ }^{25}$ The decreased funds also affected the numbers of overseas member recruitment.

To overcome the economic problems mentioned, the Indonesian government has conducted several poverty alleviation programs. World Bank has introduced an integrated social assistance reform to reduce poverty more rapidly. The program helps Indonesia to reduce poverty and inequality, and to ensure the poorest families can receive more comprehensive coverage. ${ }^{26}$ This program was in line with President Joko Widodo's infrastructure development to support economic development, especially outside Java Island. When the previous governments only focused on economic development on Java itself, President Joko Widodo's massive infrastructure program aimed to balance development in Indonesia. ${ }^{27}$ The reduced unemployment rate would

21 Stephen Elias and Clare Noone, “The Growth and Development of the Indonesian Economy”, see: https://www.rba.gov.au/publications/bulletin/2011/dec/pdf/bu-1211-4.pdf, accessed on May 23rd, 2018.

${ }_{22}$ Serikat Indonesia, https://www.spi.or.id/profil-kemiskinan-di-indonesia-2016-dalam-angka-berkurang-namun-di-desa-makin-dalam-dan-parah/, accessed on February 13th, 2017.

${ }_{23}$ Info-Spesial, http://www.infospesial.net/41194/lowongan-manajer-isis-gaji-rp-2-7-miliar//infospesialcom@infospesial, accessed on 28th September 2016.

${ }^{24}$ We Forum, https://www.weforum.org/agenda/2015/12/how-isis-runs-its-economy/, accessed on September 28 th, 2016.

25 Sindonews, http://international.sindonews.com/read/1104083/42/gaji-militan-isis-dan-bonus-budak-seks-kini-rp660-ribubulan-1461643627, accessed on September 28th, 2016.

26 World Bank: http://www.worldbank.org/en/news/press-release/2017/11/13/social-assistance-reforms-can-help-reducepoverty-faster, assessed on May 31st, 2018.

27 Detik News, https://finance.detik.com/infrastruktur/d-3872627/jokowi-kejar-pemerataan-lewat-pembangunan-infrastruktur, assessed on May 31st, 2018. 
reduce migration, both for economic and ideological purposes. According to the Indonesian Head of National Police, Tito Karnavian, poverty alleviation is a soft approach to the anti-terrorism program. According to Karnavian, the terrorists are mostly driven by three motives, namely ideology, emotion, and economy. ${ }^{28}$ To prevent the spread of terrorism, poverty would need to be alleviated to narrow the wide economic gap. Terrorism is a revenge type of the poor and economically weak groups on the existing condition which made them marginalized during the development process.

\section{Political Threats}

One aspect of political security is the protection of people's basic human rights. Through political power provided by the people, the government wields a central power to assure freedom from fear. The emergence of ISIS, along with its atrocities through terrorist actions, has demonstrated the government's failure to provide human rights protection. For example, the May 2018 bomb explosions in several churches led to fear among Christians and other minority religious groups to worship and practice their religion in peace. The Indonesian government had to respond to the challenge to create a community where the religious minorities enjoy the freedom to worship.

To securitize the issue, the government has exercised control on the flow of information, especially related to hate speech against the minorities. Following the Surabaya bomb series, the ministry of Communication and Information had blocked 1285 radical and terrorists' related accounts. ${ }^{29}$ The publications were spread in several forms, including articles, websites, and videos. Special attention was paid to Al-Fatihin (AF), an ISIS backed medium. The media featured a weekly newspaper in Indonesian, published by Daulah Islam (another name of ISIS in Indonesia). The 10th edition reported: "Junud Khilafah in Indonesia has released their own hostages and killed 6 Densus 88 personnel. Others AF articles were mostly related to promotion to conduct violence with God's reward" (2018). ${ }^{30}$

The success of the securitization program also depended on the current Indonesian government's ability to prevent political tension from an early stage. Indonesia as a major democratic country in Southeast Asia also has the most dynamic and largest number of political parties, compared to its Southeast Asian neighbors. The current Indonesian government is led by the Democratic Party of Struggle (PDIP), a nationalist party under Megawati Soekarnoputri. Joko Widodo, who is also a member of this leading party, was appointed as the Indonesian President after winning the 2014 general election. Four of Indonesian Islamic parties (the Unitary Development Party/PPP, the Prosperous Justice Party/PKS, the National Mandate Party/PAN, and the National Awakening Party (PKB)) had lost votes against nationalist parties in the previous election. The condition led to dissatisfaction of some elements of Islamic party supporters, who formed ways to pursue a goal to establish an Islamic state. With the combination of the historical background of radical movements in Indonesia since the Daulah Islam/Tentara Islam Indonesia (DI/TII) or Islamic State/Indonesian Islamic Forces, desired to establish an Islamic State in 1953, to join ISIS seemed to be bringing them closer to this destination. In addition, ISIS

\footnotetext{
28 Detik News, Kapolri Buka Strategi Lawan Teroris dalam Orasi Ilmiahnya, https://news.detik.com/berita/d-3701854/kapolri-buka-strategi-lawan-teroris-dalam-orasi-ilmiahnya?_ga=2.141088754.19794184 09.1527761178-852699379.1525661140, assessed on May 31st, 2018.

29 Detik News, Kominfo Blokir 1285 Konten Radikal Termasuk Buletin Al-Fatihhin, see: https://news.detik.com/berita/d-4026431/kominfo-blokir-1285-konten-radikal-termasuk-buletin-al-fatihhin, accessed on May 25th, 2018.

30 Detik News, https://news.detik.com/berita/4025468/polisi-selidiki-buletin-radikal-berbahasa-indonesia-terbitan-isis, accessed on May 25th, 2018.
} 
also provided military training to protect the country from outside threats. It was hoped that after being returned to Indonesia, they could spread the ideology, recruit new members, and conduct terrorist actions for propaganda purposes.

ISIS has shown the potential to spread its influence in Indonesia through education and media. The Malay-speaking media, Daulah Islamiyah (DI), have played a significant role in spreading the ISIS ideology. A DI journalist believed if jihad is not always accomplished by fighting on the battlefield, but also by writing, like the Al-Mustaqbal. Another media is Azzam Media, which publishes videos of Indonesian children practicing war in the ISIS region. ${ }^{31}$ The Indonesian government's de-radicalized program aims break down the ISIS network, to prevent the spread of ideology through extreme religious study groups. Membership recruitment through university mosques has mostly been operated at the government's higher institutions across the nation.

Another way to securitize the issue is by conducting a preemptive measure through empowering citizens. This empowerment program includes spreading as much information regarding the existence, organization system, source of funding, and anything related to the effort to gain public sympathy from society. The most important thing is to increase the ability of social media usage, so that it could filter any information that could lead to the desire to join terrorist organizations like IS.

\section{Conclusion}

The above discussion demonstrates that ISIS is indeed a threat in Indonesia. The protection of human security, including human rights and human dignity, has become one of the most fundamental objectives of the Indonesian government. Terrorist actions in almost all parts of Indonesia have caused the absence of freedom from fear. The state as the most responsible actor to provide security to the people has conducted several anti-terrorism programs. De-radicalization programs have been applied to previous radical groups, especially the ISIS returnees that previously fought in the name of ISIS, military-trained soldiers, or families that for some reason were unable to cross the ISIS borders. In general, the program was not completely successful, as indicated by the waves of terrorist attacks by ISIS returnees in Surabaya and other places in May 2018.

To prevent the spread of terrorism at an individual level, the government has also kept tabs on and contained the spread of information through the social media. Moreover, the police and other security apparatuses have been developing equipment, devices, and human resources to prevent terrorist actions organized through the social media. Since the recruitment process is conducted on an individual basis, or using social media closed groups, the anti-terrorism police has been challenged by the inability to apply a surveillance mechanism. Therefore, cooperation with every element of society has become a significant requirement.

The role of Special Forces 88 within the Indonesian police is another mechanism to provide security and securitize the issue. In addition to BNPT, the two units were examples of the government's effort to institutionalize the de-radicalization program. However, the Indonesian government needs to improve the processes and mechanisms to provide better protection and security. De-radicalization program should also include the prevention of hate speech of radical Moslems directed against religious minorities groups. The biggest enemy to ISIS’s development is cultural Muslim groups that desire to practice their religion peacefully.

${ }^{31}$ CNN Indonesia: http://www.cnnindonesia.com/internasional/20150319160810-112-40369/isis-di-indonesia-juga-pakai-mediasosial/, accessed on August 9th, 2015. 
This majority of traditional Muslims should be able to practice a peaceful Islam and should not be tempted by ISIS propaganda with radical beliefs. In addition, the government needs to be proactive in promoting and inculcate tolerance in religious practice from an early age. Last but not least, Indonesia also needs a strong legal basis that sets clear standards for hate statements that are widely spread by the ISIS and other radical groups in vulgar ways.

\section{References}

Berger, J. M., \& Morgan, J. (September 15th, 2015). The ISIS Twitter census: Defining and describing the population of ISIS supporters on Twitter. The Brookings Project on US Relations With the Islamic World, Analysis Paper. Retrieved from http://www.brookings.edu/ /media/research/files/papers/2015/03/isis-twitter-census-berger-morgan/isis_twitter_census_berg er_morgan.pdf

Hataley, T. S., \& Nossal, K. R. (May 17th, 2018). The limits of the human security agenda: The case of Canada's response to the Timor crisis. The Journal of Global Change, Peace and Security. Retrieved from https://www.tandfonline.com/doi/full/10.1080/1478115042000176148?scroll=top\&needAccess=true

Kfir, I. (2015). Social identity group and human (in)security: The case of Islamic State in Iraq and the Levant (ISIL). Studies in Conflict and Terrorism 38(4), 233-252. Retrieved from https://www.tandfonline.com/doi/abs/10.1080/1057610X.2014.997510 